\title{
アダプティブキャンセラ方式による同時送受信技術の実験的検討
}

$\begin{array}{llll}\text { 学生員 } & \text { 阿部 } & \text { 精順 } & \text { (筑波大) } \\ \text { 正員 } & \text { 渡辺 } & \text { 秀明 } & \text { (防衛庁) } \\ \text { 非会員 } & \text { 平澤 } & \text { 一紘 } & \text { (筑波大) }\end{array}$

\section{Simultaneous Transmission and Reception System by Adaptive Cancelling}

Kiyonobu Abe, Student Member (University of Tsukuba), Hideaki Watanabe, Member (Japan Defence Agency), Kazuhiro Hirasawa, Non-Member (University of Tsukuba)

\begin{abstract}
Airborne and shipborne radar, communication and the related radio wave systems with simultaneous transmission and reception system (STR) have limited spatial interval between the transmitting and the receiving antenna. Thus suppression of self-interference due to the strong transmitted signal is an important problem. We have made an engineering model of STR with an adaptive cancellation technique, and evaluated for three kinds of interferences: CW, pulse, wideband signals.
\end{abstract}

キーワート：適応ノィズキャンセラ, アダプティブフィルタ

\section{1. まえがき}

一般に，艦船及び航空機では、レーダ，通信機器等の電 波器材を搭載する際，搭載スペースに制限があるため，各 装置の空中線を離隔することが困難となる。このため, 複 数の電波器材が近接した周波数で送受信を行うと送信波の 回り込みにより，他の電波機器において目標信号の検出が 妨害される場合がある。現状では，送信と受信の時間帯を 分けて，時分割で送受信を行うょうになっている。しかし， 時分割の送受信では，送信及び受信の効率が劣化すること から、レーダに执いては目標の知・追尾, 電波探知機器 等においては目標信号の監視に支障をきたすことがある。 従って，近接した周波数を用いて同時に送受信を行う場合， 干渉波（送信波の受信空中線への回り込み）を抑圧・除去 し，目標波 (対象目標からの受信波) のみを検出すること は重要な課題である(1)。このような干渉波を㧕圧する方 法として他に，位相相殺回路によって送信電力の受信機へ の回り込みを除去する方法等 ${ }^{(1)}$ や送受信空中線の偏波方 向を変化させることにより，送受信空中線のアイソレーシ ヨンをとる力法(2)などがあげられる。

一方，信号処理技術の発展に伴い，アダプティブキャン セラ方式 ${ }^{(3)}(4)$ が各種レーダのクラッタ及び妨害波の低減 化に利用されてきており，最近の研究では，この方式が同 時送受信を行うシステムに応用され，その有效性が報告さ れている(ら)〜(7)。

このようなことから，我々は，近接した送受信空中線間 において，干渉波を抑圧しながら目標波を検出する目的で， 同時送受信実験装置（以下「本装置」）を試作しアアダプ
ティブキャンセラ方式による干渉波の抑圧効果について確

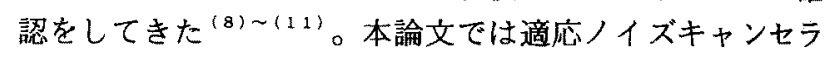

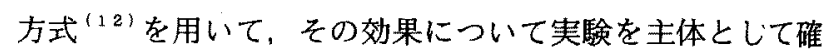
認した結果を述べる。

なお，干渉波の抑圧・除去手法として現実の運用を考慮 したときに，電波機器を改造して信号発生部からの信号を 取り出し，直接参照信号として用いることができる場合と 電波機器の改造が困難であり，信号発生部からの信号を直 接取り出せない場合に, 送信空中線の近傍に空中線を設置

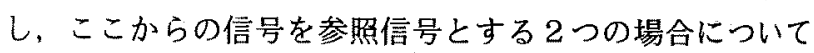
検討をする。

本論文では，第 2 節で本装置の基本構成及び動作原理， 第 3 節で実験方法, 第 4 節で実験結果及び考察について述 べる。

\section{2. 同時送受信実験装置の構成及び動作原理}

<2.1>基本構成本装置の構成を図 1 に示す。本装置 は, 信号発生部, 送信部, 受信部, 信号処理部, 受信及ひ 送信空中線から構成されており， CW，パルス等の各種 信号を用いた実験が可能である。本装置では，信号発生部 において，信号を発生させ，送信部を通して電波を放射す る。次に受信空中線では目標波と干涉波（送信空中線から の回り込み）を取り込み，受信部で IF 帯に変換された後， $\mathrm{AD}$ 変換器でディジタル信号に変換され，信号処理部にお いて, 信号発生部からの参照信号を基に干渉波の除去处理 を行うょうになっている。信号処理部では， $\mathrm{AD}$ 変換器か ら送られてくるディジタル信号を一旦, 記憶装置に蓄え, オフラインで信号処理を行う。 


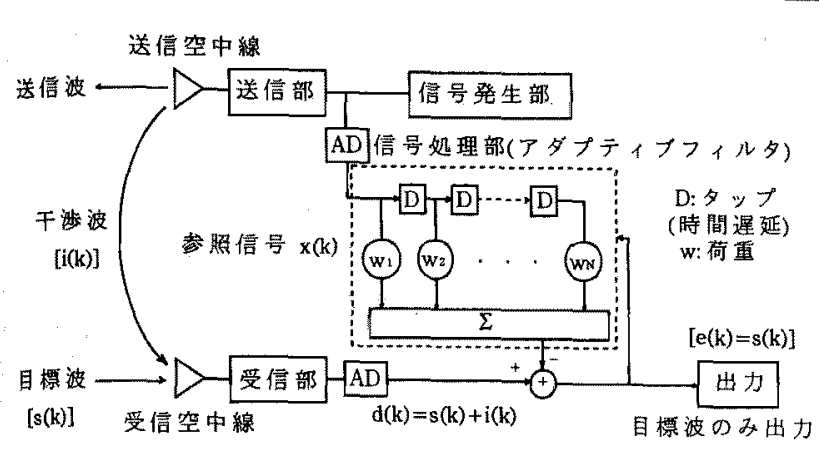

図 1 同時送受信実験装置の基本構成

Fig. 1. Fundamental configuration of the STR system

〈2.2〉干涉波抑圧の方法 干涉波の抑圧方法としては、 適応ノイズキャンセラ方式を用いている。本方式は，アダ プティブフィルタを用いて，末知伝搬系のレプリカを作成 することにより，干渉波を除去する信号処理方式である。

サンプリング時刻 $k T_{s}\left(k=0,1,2, \cdots\right.$ はサンブル番号, $T_{s}$ はサンプル周期）における信号発生部からの参照信号ベタ

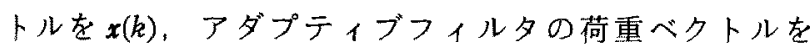
$w(k)$ とし，目標波の信号を $s(k)$ ，干渉波の信号をi(k)とす ると受信部における受信信号は $d(k)=s(k)+i(k)$ となる。ま た, 消え残り誤差信号 $e(k)$ は,

$e(k)=d(k)-w(k)^{T} x(k)$

となる。Tは行列の転置を表す。ここでアダプティブフ イルタのタップ数を $\mathrm{N}$ とすると，w(k)及び $\boldsymbol{x}(k)$ は，

$$
\begin{aligned}
& \boldsymbol{w}(k)=\left(w_{1}(k), w_{2}(k), \cdots, w_{N}(k)\right)^{T} \\
& \boldsymbol{x}(k)=(x(k), x(k-1), \cdots, \quad \boldsymbol{x}(k-N+1))^{T}
\end{aligned}
$$

である。このとき，干渉波と目標波は，相関加弱いものと すると, $e(k)$ の期待值 $E\left[|e(k)|^{2}\right]$ を最小にする最適荷重 $w_{\text {opt }}$ は，次のように表される。

$$
w_{\text {opt }}=R^{-1} p
$$

ここで, $R=E\left[x(k) x(k)^{T^{*}}\right]$ は $x(k)$ の自己相関行列, $p=E\left[d(k)^{*} x(k)\right]$ は $d(k)$ と $x(k)$ の相互相関べクトルであ る。ただし，*は複素共役を表す。このい, を用いること により受信信号 $d(k)$ に含まれる干渉波成分 $i(k)$ が最適に 推定されるため， $e(k)$ 中の干渉波成分の電力は最小とな る。

\section{3. 実験方法}

本装置の性能を確認するため，電波暗室内で事際に送受 信実験を行った。実験の諸元を表1に，測定系統のブロッ クを图2に示す。目標波は，標準信号発生器により発生し， 架中線から空間に送信され，送信波（干渉波）は，信号発 生器により発生し, 変調部により，変調され空間に送信さ れる。目標波を送信する空中線は，ホーンアンテナで受信 空中線の正面方向から，5m 離した位置に置き，干渉波を 送信する空中線むまたホーンアンテナで，30度の方向に $0.7 \mathrm{~m}$ 離した位置に設置した。また，送信波の信号を参照
表 1 実殹の諸元

Table 1. Configuration of the STR system

\begin{tabular}{|l|l|}
\hline 目標波周波数 & $9500.1 \mathrm{MHz}$ \\
\hline 送信波(千涉波)周波数 & $9500.0 \mathrm{MHz}$ \\
\hline 局部発振器周波数 & $9490.0 \mathrm{MHz}$ \\
\hline 送信波/目標波比 & $\begin{array}{l}20 \mathrm{~dB} \\
\text { (受信部入力端、带域 } 50 \mathrm{MHz} \text { ) }\end{array}$ \\
\hline
\end{tabular}

信号として直接用いない場合には，送信空中線の近傍に参 照信号を取り入れる空中線を設置し、そこからの信号を参 照信号とした。なお，参照信号用空中線の送信波と目標波

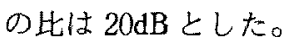

受信空中線で受信された信号は，受信部でIF 帯にダウ ンコンバートされた後, サンプリング周波数 $100 \mathrm{MHz}$ ，量 子化ビット数 10 ビットで $\mathrm{AD}$ 変換され，ディジタル信号 として記録される。信号処理部では，記録された信号の干 涉波抑圧処理及び各種の解析を行えるようになっている。

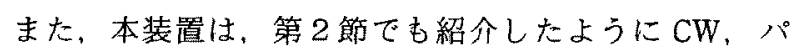
ルス等各種信号を用いた実験が可能となっているが，今回 は基礎的な干渉波抑王のデータを得るため，目標波につい ては，CW，干涉波については，CW，パルス(パルス

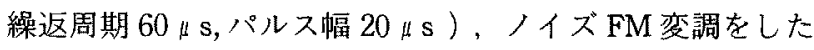
広带域信号（带域 $10 \mathrm{MHz}$ ) とした。

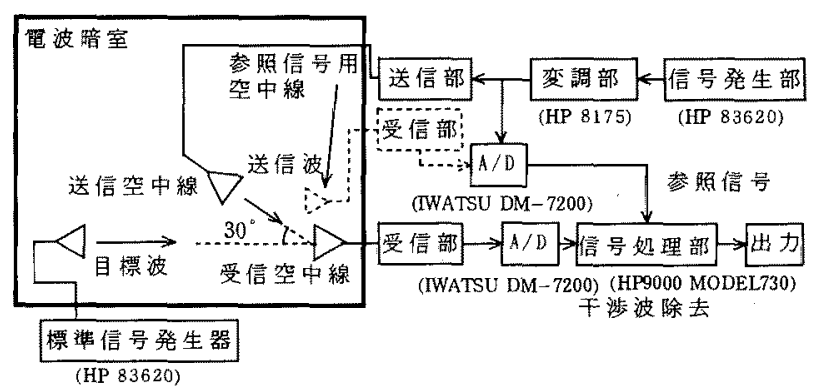

图 2 同時送受信実験装置の測定系統図

Fig. 2. Experimental apparatus of the STR system

\section{4. 実験結果及び考察}

〈4.1〉参照信号を直接信号発生部からとった場合目

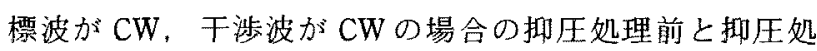
理後の受信信号をフーリエ変換した結果を図 3 に示す。な お，干渉波及び目標波のレベルの測定は，周波数分解能を $6.1 \mathrm{kHz}$ の帯域幅で測定をしている。また，アダプティブ フィルタの時間䢭延は，サンプリング周期と同じ 10ns, タップ数は 15 とした。

干渉波が $\mathrm{CW}$ の場合，抑圧処理前後で目標波の損失が ほとんどない。干渉波はノイズレベルにまで落ち込んでお り，抑圧度が高いことが観测される。アダプティブフィル 夕は，単一の周波数に対しては周波数的にシャープなノッ 

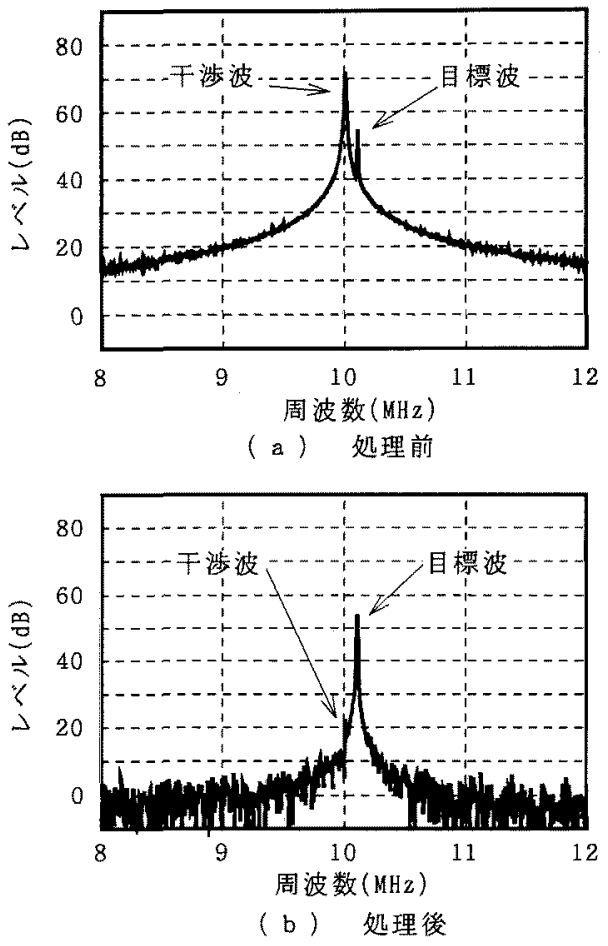

図 3 干涉波がCWの場合

Fig. 3. Experimental results (Interference: $\mathrm{CW}$, Target: $\mathrm{CW}$ )

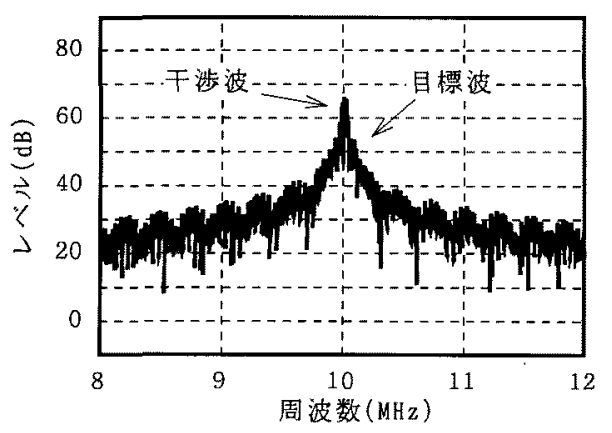

(a) 処理前

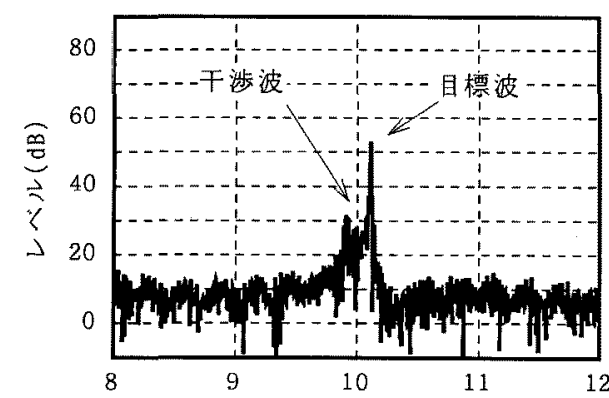

周波数 (MHz)

(b) 処理後

図 4 干涉波がパルスの場合

Fig. 4. Experimental results (Interference: pulse, Target: CW)

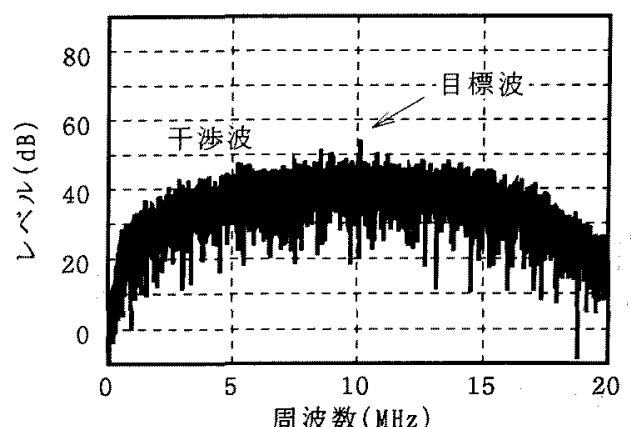

(a) 処理前

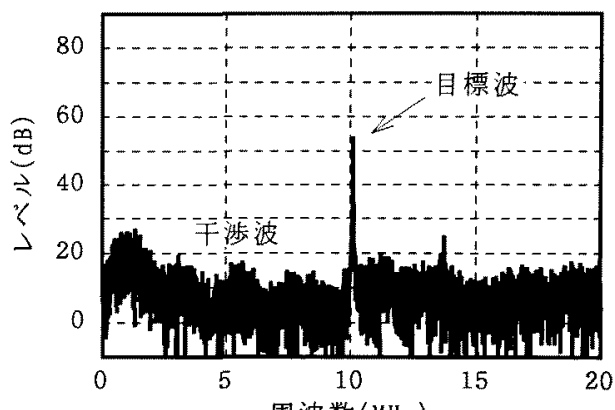

周波数 $(\mathrm{MHz})$

(b) 処理後

図 5 干涉波が広带域信号の場合

Fig. 5. Experimental results

(Interference: wideband, Target: $\mathrm{CW}$ )

チフィルタを形成できるためと考えられる。

干渉波がパルスの場合を図 4 に示す。干渉波がパルスの 場合にも目標波の損失は，ほとんどなかった。干涉波の㧕 圧については，干渉波が $\mathrm{CW}$ のきに比べ，干涉波の抑 艮度が少化した。これは，干渉波がパルスであるため，干 渉波の帯域が広がっているためである。

干涉波が広带域信号の結果を図5に示す。この図は，帯 域が広帯域であることを示すため，横軸が $0 \sim 20 \mathrm{MHz}$ と なっている。干渉波が広帯域信号である場合にも，目標波 の損失はほとんど無かった。干涉波が $\mathrm{CW}$ のきほど， 大きく抑圧はしていないが，干渉波の抑圧は広帯域に抑圧 している。広带域信号の場合あらゆる周波数成分を満遍な く持っているため，広帯域に学習ができ，アダプティブフ イルタで広帯域に未知伝搬系を模擬することができるため であると考えられる。

〈4.2〉参照信号を空間からとった場合参照信号を送 信空中線の近傍に置いた空中線からの信号とした場合の結 果を図 6〜8に示す。それぞれ干渉波が $\mathrm{CW}$ ，パルス， 広帯域信号である。すべてに其通していることであるが, 参照信号に目標波成分が含まれており，参照信号が目標波 と相関があるため，目標波に損失がみられる。また，千涉 波が CW 場合，干渉波成分の消え残りも大きくなり， 性能の劣化が大きいが，これは直接信号発生器からの信号 


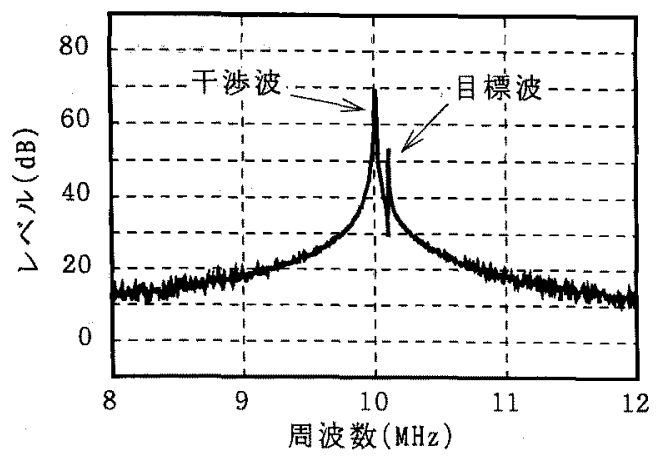

(a) 処理前

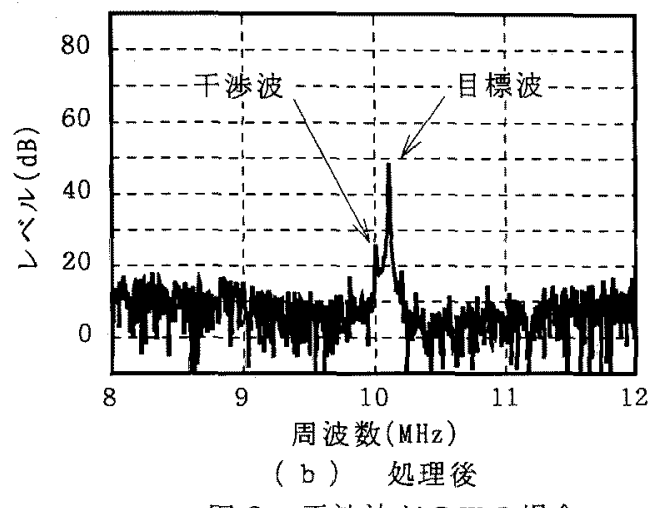

図 6 干涉波が C W の場合

Fig. 6. Experimental results (Interference: $\mathrm{CW}$, Target: $\mathrm{CW}$ )
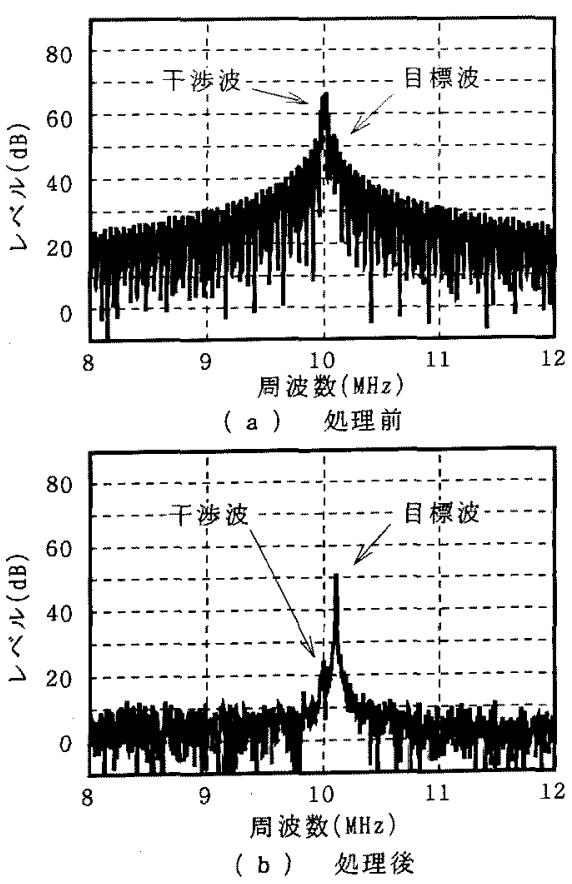

图 7 干涉波がパルスの場合

Fig. 7. Experimental results (Interference: pulse, Target: $\mathrm{CW}$ )
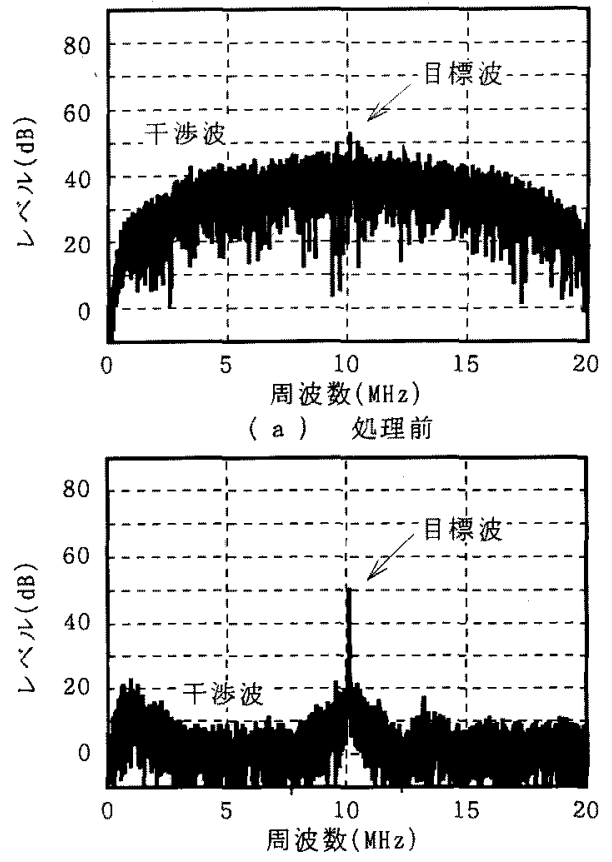

(b) 処理後

図 8 干涉波が広带域信号の場合 Fig. 8. Experimental results (Interference: wideband, Target: $\mathrm{CW}$ )

を参照信号とした場合，単一の CW 信号であるが，空間 からの信号を参照信号とすると単一の周波数ではなくなる ため，それだけ帯域が広がるため抑圧度が低くなると考え られる。

$\langle 4.3\rangle \mathrm{S} / \mathrm{l}$ 改善度 ここで, IMF（IMprovement Factor: S/I 改善度) を以下のように定義し，タップ数によ る変化を図9に示した。

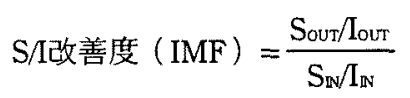

$\mathrm{I}_{\mathrm{N}}$ ：送信波（干渉波）の入力レベル

$\mathrm{S}_{\mathrm{IN}}$ : 目標波の入力レベル

$\mathrm{I}_{\mathrm{OUT}}$ ：処理後の送信波（干渉波）レベル

$S_{\text {OUT }}$ : 処理後の目標波レベル

干啮波が CW の場合，IMFは $65 \mathrm{~dB}$ 以上と高く、タップ 数による変化はほとんど見られない。これは、単一周波数 の干渉波は、フィルタのタップが一つでも十分㧕压できる ことを示している。

干渉波がパルスの場合、タップ数による改善度に変化が ほとんど見られないのは，アダプティブフィルタの働きが $\mathrm{CW}$ を抑圧する働きと同一になっているため，広帯域に拆 
圧できないためと考えられる。

参照信号を信号発生器から直接とったときに，干渉波が 広带域信号の場合，タップ数の增加とともに IMF が改善 されている。これはアダプティプフィルタが単一のタップ では単一周波数の干渉波にしか対応できないが、タップを 増加することで対応できる周波数が増大し，広带域化する ことを意味している。ただし，タップ数は多ければ多いほ どIMFが向上するわけではなく报う信号により，最適な タップ数があると考えられる。

また，参照信号を空間から取り込んだ場合には，空間的 なフィルタを形成でき，アダプティブアレーの動作が可能 となる。そのため IF 带での信号処理よりも， RF 带での 空間フィルタの帯域が広いため，タップ数が少ない場合で も広帯域な抑圧ができることを意味している。

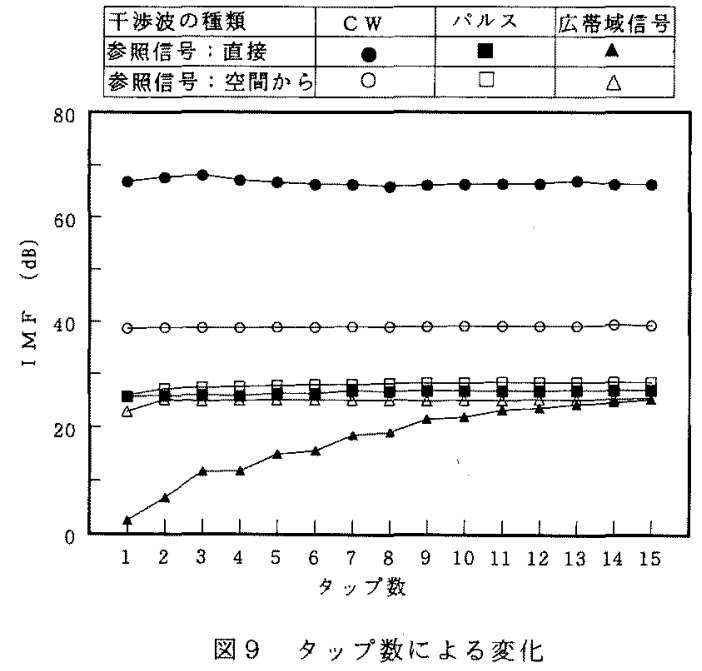

Fig. 9. Improvement factor (IMF) vs. tap number

\section{5.むすび}

送受信空中線間のアイソレーションを信号処理により確 保する方法について解析を行うため, 同時送受信実験装置 を試作し，アダプティブキャンセラ方式について，各干涉 波（CW，パルス，広带域信号）の抑圧度を調心゙た。そ の結果， $\mathrm{CW}$ 信号では 60 数 $\mathrm{dB}$ の干渉波の抑圧ができ， 干渉波抑圧の一手法として有効であることが実験的に確認 できた。寒際のレーダ等に応用する場合、レーダの送受信 空中線を分離した形態を想定し，送信電力を $70 \mathrm{dBm}$ とし， 最小受信感度を $-80 \mathrm{dBm}$ としたときに，送信電力がその まま受信機に入力されると考えるとそのアイソレーション は $150 \mathrm{dBm}$ 以上必要となる。そのため，現実的には，送受 信空中線間のアイソレーションをとるために，アンテナの 配置、電波吸収体の利用などを含めて信号好理による干渉 波の抑圧を考える必要がある。

今後は，他の方式や方式の組み合わせを考慮した実験を 行うとともに，手法のリアルタイム化及びコヒーレントな 信号や時変的な信号にも対応可能な, 同時送受信を検討す
る予定である。また，春際のレーダ等の電波橙器に適用し た実験を行う必要がある。

最後に，本研究における奏験に御協力を頂いた防衛庁技 術研究本部第 2 研究所電波第 2 研究室の島野不二郎技官に 感謝致します。

(平成 8 年 7 月 25 日受付, 平成 8 年 12 月 6 日再受付)

\section{参考文献}

(1) Van Brunt, L. B. : Applied ECM, Electronic Warfare Engineering, pp.262-276, 1978

(2) 橋本・請川：「送受信アイソレーション向上に関する 基礎的検討」，日本航空宇宙学会誌，41，477, pp.597-599 (1993-10)

(3) 近藤・大橋・奏森：「計測・センサにおけるディジタ 儿信号処理」，昭晃堂，(1993)

(4) S. Haykin（武部幹訳）：「適応フィルタ入門」，現 代工学社, (1987)

(5) M. E. Brown: "Interference Cancellation in RF Signals Using Adaptive Array Techniques", Master Thesis, Air Force Inst. of Tech., Wright-Patterson AFB, OH, (1990).

(6) Raytheon Co., Electromagnetics Systems Div., "Adaptive Cancellation Techniques", Naval Research Laboratory, Washington DC, AD-A136946, (1983).

(7) 大室・大橋·立花・近藤：「サイドローブ・キャンセ ラにおける信号処理方式の比較㛟討」，信学技報, SANE82-2，（1982）

（8）阿部・米倉・渡辺・平澤：「レーダ応用のための同時 送受信技術について」，信学技報，SANE94-58 (1994)

(9) H. Watanabe, K. Abe and T. Nakazawa:"Simultaneous Transmission and Reception System", Proc. the ISNCR94, pp.247-252 (Nov. 1994)

(10) 渡辺 · 阿部 - 米倉 - 小林 - 伊藤 - 近岡 - 保科 - 岡村 : 「ニアフィールドでの干渉波を抑圧するナルビーム形 成」，信学技報, SANE94-89 (1995)

(11) 米倉 ·渡辺 · 阿部 ·保科 ·岡村 : 「同時送受信のパル スドップラーヘの応用」，信学技報，SANE95-82 (1995)

(12) B. Widrow, J. R. Glover., J. M. McCool, J. Kaunitz, C. S. Williams, R. H. Hearn, J. R. Zeidler, E. Dong and R. C. Goodlin: "Adaptive Noise Cancelling: Principles and Applications", Proc. IEEE, 63, 12, pp.1692-1716 (Dec. 1975) 


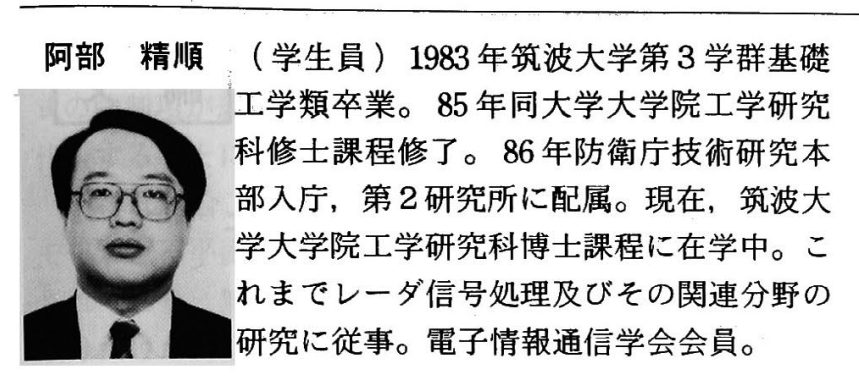

渡辺 秀明 （正員）1977 年慶応大学工学部卒業。79 年同大学大学院修士課程終了。同年防衛庁
技術研究本部入庁, 現在に至る。工学博士。
これまでレーダ信号処理及びその関連分野
の研究に従事。電子情報通信学会会員。

平澤一紘 (非会員) 1964 年慶応大学工学部卒業。 71 年 Syracuse 大学大学院修了 ( Ph.D )。 同大学勤務, 自営コンサルタントを経て, 現在, 筑波大学電子 - 情報工学系教授。電 波の放射・散乱の制御、フェーズドアレー, 移動通信用アンテナ, アダプティブアレー の研究に従事。電子情報通信学会, テレビ ジョン学会会員。 